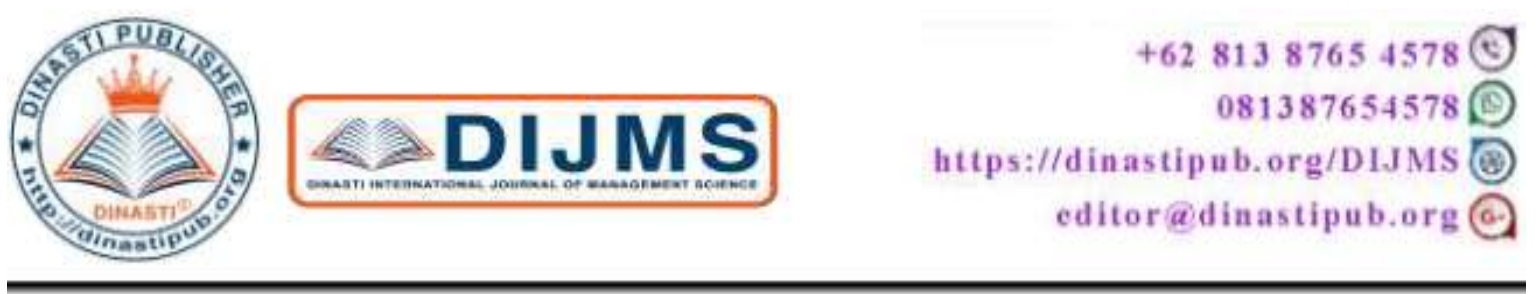

\title{
THE ROLE OF LEADERSHIP, ORGANIZATIONAL COMMITMENT AND COMPETENCE IN THE ORGANIZATIONAL CULTURE OF THE STATE CIVIL APPARATUS AND ITS IMPLICATIONS FOR THE PERFORMANCE OF PUBLIC SERVICES IN THE TRADE AND INDUSTRY OFFICES OF REGENCIES
}

\section{Syahrian $^{1)}$}

1) Universitas Pasundan, Indonesia

\begin{tabular}{|c|c|}
\hline $\begin{array}{l}\text { ARTICLE INFORMATION } \\
\text { Received: } 25 \text { December } 2019 \\
\text { Revised: } 30 \text { December } 2019 \\
\text { Issued: } 1 \text { January } 2020 \\
\text { Corresponding author: first author } \\
\text { E-mail: } \\
\text { syahrian2014@gmail.com } \\
\text { DOI:10.31933/DIJMS }\end{array}$ & $\begin{array}{l}\text { Abstract: This research was conducted because West Java } \\
\text { Province is a province with a large population when } \\
\text { compared to other provinces in Java and still has limitations } \\
\text { on efforts to improve the performance of public services in } \\
\text { the trade and industry service district / city in West Java } \\
\text { Province, where the performance of public services is still } \\
\text { not good. This was allegedly due to the organizational } \\
\text { culture of the state civil apparatus that did not meet the } \\
\text { standards. The purpose of this study was to determine and } \\
\text { examine the role of leadership, organizational commitment } \\
\text { and competence in the organizational culture of the state } \\
\text { civil apparatus and its implications for the performance of } \\
\text { public services in the trade and industry offices of regencies } \\
\text { / cities in West Java Province. This study uses SEM analysis } \\
\text { tools with a number of samples, as many as } 390 \text { respondents. } \\
\text { The sampling technique used is Proportional Stratistified } \\
\text { Random Sampling. The results of the analysis obtained a } \\
\text { significant influence both partially and simultaneously, from } \\
\text { the Role of Leadership, Organizational Commitment and } \\
\text { Competence to the organizational Culture of the Civil } \\
\text { Service of the State, as well as a significant influence on the } \\
\text { Work Culture of the State Civil Apparatus on the } \\
\text { Performance of Public Services in the trade and industry } \\
\text { services. district / city in West Java Province. } \\
\text { Keywords: Leadership Role, Organizational Commitment, } \\
\text { Competence, State Civil Service organizational Culture, } \\
\text { Public Service Performance. }\end{array}$ \\
\hline
\end{tabular}

\section{INTRODUCTION}

The quality of human resources is a major issue in the development process for developing countries, especially in the development of the Human Development Index (HDI). Education is important in the effort to transform cultural values as cultural inheritance activities from one generation to another. These cultural values underwent a process of transformation from previous generations to present and future generations. 
The emergence of discourse about the need for a development decentralization process, which can be interpreted as a process of devolving decision making authority and development financing from the center to the regions. The discourse emerged along with the emergence of awareness in the economic context, especially in the field of trade and industry. The discourse of regional autonomy can have a positive impact including hopes for decreasing economic distortion, increasing public services, and improving accountability to local communities, as well as increasing the mobilization of funds in the region. Giving rise to the initiative of the regional government to form one of the Regional Apparatus in the form of the Office of Trade and Industry at the Provincial, Regency and City Level as well as being a representation and extension of the central government agencies (Ministry of Trade and the Ministry of Industry).

The government is certainly quickly observing the fundamental changes to various laws in the political sphere from being centralized to being decentralized. As for the juridical basis in carrying out government reforms, the government issued 2 (two) Laws (Law), namely Law Number 22 of 1999 concerning Regional Government which was updated with Law Number 32 of 2004 as amended by (juncto) with Law Number 232014 and Law No. 25/1999 concerning Fiscal Balance between the Center and Regions which was updated with Law No. 33/2004. Many parties welcomed the issuance of this constitution, but not a few were concerned about the negative impacts that might arise with the delegation of authority ( power delegation and fiscal decentralization that is so broad and frontal.

The existence of the two constitutions needs to be supplemented by other laws, including Law Number 14 of 2008 concerning Openness of Public Information, Law Number 25 of 2009 concerning Public Services, and Law Number 23 of 2014 concerning Regional Government.

The implementation of the constitution is still many things that lead to misunderstandings and even controversy between the two parties, the fact often shows that almost all provincial, district / city local governments have not able to carry out services to the public well by the State Civil Apparatus (ASN), even local governments have problems in misuse and misappropriation of APBD finances. That is because there are non-compliance and non-discipline of the implementation of the aforementioned constitution.

Weiss (2006) explains that Indonesian bureaucracy is technocratic power and arrogance. The results of the evaluation of the Central Government found that most of the regions spent the regional budget not in accordance with the principles of effectiveness, efficiency, economic and productive (E3P). Based on the data above, it illustrates that the purpose of autonomy is to improve services and welfare far from the expectations mandated in various laws relating to public services and the implementation of development in the era of decentralization.

In terms of the pattern of implementation, public services still have various weaknesses including:

a. Less responsive and informative.

b. Less accessible.

c. Lack of coordination.

d. Bureaucratic.

e. Less willing to listen to complaints / suggestions / aspirations of the community. 


\section{f. Inefficient.}

Human development index as a representation of the quality of human resources, is a major element in organizations, where HR is able to set goals, think creatively and act innovatively, and achieve organizational goals. Human resources trigger creativity in every organization. Without quality human resources, it will be impossible for the organization to achieve its goals.

Sedarmayanti (2017) explains motivation is a willingness to spend a high level of effort toward organizational goals that are conditioned by the ability of efforts to meet individual needs. Leadership and motivation are two inseparable things. In most cases, an individual's motivation will arise due to the influence of an effective leader. So, the effectiveness of leadership will show how to effectively motivate its members. The author is interested in establishing that the observation unit is the District / City Trade and Industry Office in West Java Province as follows:

1. The District / City Trade and Industry Office in West Java Province is a regional apparatus that has a strategic role in determining the success of development, especially in the development of regency / city trade and industry in West Java Province.

2. The development of trade and industry in the era of globalization is very fast and increasingly dynamic, therefore regional apparatuses are demanded high organizational commitment from the apparatus, so that they will be able to improve the performance of public services, which in turn will improve company performance

3. Considering the Provincial and District and City Trade and Industry Offices as well as being representatives and representatives of the central government agencies (Ministry of Trade and the Ministry of Industry), to become regional apparatuses capable of developing the Trade and Industry sector as one of the main forces for economic development in Regencies / Cities in West Java Province, it requires the existence of a leadership role, organizational commitment and competence to the culture of the State civil service organizations and their implications for the performance of public services of the District / City Trade and Industry Office in West Java Province.

Starting from the basis of the provisions of the law, the basis of theories, and the empirical basis that has been explained in the background of the study, the authors conducted a study: "The role of leadership, organizational commitment and competence to the organizational culture of the state civil apparatus and its implications for the performance of public services in the trade service and industrial districts / cities in West Java Province ".

\section{LITERATURE REVIEW}

Management comes from ancient France, namely management, which means the art of carrying out and managing. Management is translated into Indonesian into management (management) (Husaini Usman, 2013: 5-6). As stated by George R. Trerry (2014: 9) provides management definition as follows: "Management is the scope of activities to achieve the goals, carried out by individuals who contribute their best efforts through predetermined actions". "Management is the scope of activities to achieve goals, carried out by individuals who contribute their best efforts through predetermined actions ".

Gary Dessler (2015: 4) mentions that there are 5 (five) specific activities involved in each management function including: Planning, Organizing, Staffing, Leadership, Control 
The task of management is to utilize human resources optimally for the achievement of organizational goals.

Tyson (2006: 63) provides the definition of human resource management as follows: human resource management is a term which stresses the development of people as assets rather their control as cost, and places people management at the strategic heart of business planning. Human resource management is a form of emphasis on developing people as assets that are controlled through costs and management of the placement of people in business strategies. Dessler (2011: 5) explains that human resource management is the policy and practice of determining aspects of human or human resources in management positions, including recruiting, screening, training, giving awards, and evaluating.

The role of leadership in meeting the challenges of the 21 st Century is not only at the top of the organization but also under all organizational resources moving forward. In line with this, Ann Howard (2006: 57) a President of the Leadership Research Institute and Senior Consultant from International Development Dimensions explained, a leader must have high involvement. The role that helps leadership with high involvement is designed for an organization, built for speed, flexibility, quality, and service, which is important for global competition.

Gannon in M.Toha (2010) defines a leader that is a boss who influences the behavior of his subordinates. So in outline the leader can be defined as a charismatic figure who is able to make good decisions and be able to influence others to achieve their stated goals. M. Toha (2010) leadership is an activity to influence the behavior of others (followers or subordinates) so that other people want to follow what they want. From this definition, other people can be interpreted as followers or subordinates and leadership as an effort to influence the activities of followers through the communication process to achieve certain goals. This definition shows that leadership involves the use of influence and therefore all relationships can constitute leadership efforts. The second element of the definition concerns the importance of the communication process. Clarity and accuracy of the communication process affect the behavior and achievements of followers. Other elements of the definition focus on achieving goals. Robbins and Judge in Angelica, Cahyani, and Rosyid (2009: 100) define "organizational commitment as a condition in which an employee sides with a particular organization and the employee's goals and desires to maintain membership in the organization". So high job involvement means taking the side of the organization that recruits the individual.

Luthans (2006) defines organizational commitment as an attitude that reflects employee loyalty to the organization and the ongoing process by which members of the organization express their concern for the organization and its continued success and progress. Robbins (2006) defines organizational commitment as a condition in which an employee sides with a particular organization and its objectives and intends to maintain membership in the organization. Commitment to a high organization can be interpreted that employee loyalty (loyalty) to the organization that employs it is high.

Based on the above definition, it can be concluded that organizational commitment is the level of trust in which an employee sided with a particular organization and its objectives and intends to maintain and maintain membership in the organization.

Etymologically competence as stated by Scale in Sutrisno (2009: 202) comes from the word competence which means skill, ability, and authority. Besides that, it also has the same 
understanding as capability (capability), someone who is competent who has the ability, knowledge and expertise to do something efficiently and effectively. The word competency, basically the word competent, means capable or skilled. 1. Competence is the level of a person's ability to carry out the authorities and responsibilities held in carrying out their duties effectively efficiently.

2. Conception of competence includes 3 (three) aspects, namely:

a) basic abilities possessed by each person concerning traits, motivations and motivations; b) technical abilities possessed by someone in carrying out technical tasks; c) a person's ability in terms of management, leadership and administration.

3. Five (5) basic characteristics of competencies, including: Motives (traits), Traits, Personal concepts, Knowledge, Skills.

The thinking of experts such as Koentjaraningrat, (2001: 72) Culture can also be interpreted as: "The whole system of ideas and tastes, actions and works produced by humans in social life that is owned by them through the learning process in accordance with ethnic, professional and regional uniqueness". Danim (2003: 148). Explain the cultural concepts of mental programs which are divided into three levels, namely: 1). individual level, that is, a unique mental program that only one person has, two people will not have the exact same mental program. 2). collective level, which is a mental program that is owned by some, not all humans.

Patterns of habituation in a culture as a recognized value can form a pattern of behavior in this case Ferdinand Tonnies (2011) divides habits in several senses, including:

1. Habit as a daily objective reality which is a fairness both in attitude and in daily appearance.

2. Habits as self-created rules that are habits that are born from the educator himself who later becomes a distinguishing characteristic of the others.

3. Habits as an embodiment of willingness to do something that is a habit that was born from motivation and initiatives that reflect personal achievement.

Cultural value is a system can be a basic assumption of an organization to move in improving its performance, one of which is the formation of a strong culture that can influence. Mc Kenna, etal, Terj. Toto Budi Santoso (2012: 19), argues that: Strong culture underlies the key aspects of implementing organizational functions in terms of efficiency, innovation, quality and supports the right reaction to get them accustomed to events, because the prevailing ethos accommodates resilience. The thinking of experts such as Schermerhorn et. al. (2010: 366) defines organizational culture as follows: organizational culture or corporate culture is the system of shared actions, values, and beliefs that develop within an organization and guides the behavior of its members. Organizational culture is a system of sharing activities, values and beliefs to develop the organization and guide behavior for members. If culture is an important assumption that is sometimes rarely expressed formally but has been adopted from internal input from other organizational members.

Culture can be interpreted in full as a value, concept, habits, feelings taken from the basic assumptions of an organization which is then internalized by its members. A professional with character and strong culture will improve his performance in the organization and at the same time improve his self-image.

Etymological performance is derived from English, namely performance. Performance comes from the word "to perform" which has the meaning of entries (entries), a lot of explanation about the meaning of these entries from various notions of input that are relevant to the notion of performance. The conclusion is based on the thought of Lijan Poltak 
Sinambela in Hayat (2017: 58) that performance is the implementation of a job and the refinement of the job is in accordance with its responsibilities, so that it can achieve results as expected. In the Big Indonesian Dictionary the definition of service is stated that "Service is an effort to help prepare (take care) what is needed by others. While the definition of service in Oxford (2000) is defined as "a system that provides something that the public needs, organized by the government or a private company". Therefore, the service functions as a system that provides what is needed by the community.

While the term public, which comes from English (public), there are several meanings, which have various meanings in Indonesian, namely general, community, and country. Public in the general sense or the community can be us find in terms of public utilities (public companies), public offering (public offering), public ownership (public property), and public relations (public relations), public service (public service), public interest (public interest) etc.

In the sense of the state one of them is a public authority (state authority), public building (state building), public revenue (state revenue) and public sector (state sector). In this case, public services show the term public is closer to the understanding of society or the public. However, the public understanding inherent in public service is not entirely congruent with the understanding of the community. Nurcholish (2005: 178) provides a public understanding as a number of people who have the right thoughts, feelings, hopes, attitudes and actions that are right and good based on the values of the norms they have.

Law Number 25 of 2009 concerning Public Services in Article 1 paragraph (1) provides the definition of public service is an activity or series of activities in the framework of meeting service needs in accordance with the laws and regulations for every citizen and resident of goods, services and / or administrative services provided by public service providers.

On the other hand, the private sector plays a role in the provision of private goods and services. The situation of competition always arises in the provision of goods and services by the private sector. There are times when the government also provides private goods services. To avoid the crowding out effect, where the government acts as a competitor to other market players, it needs to be clearly regulated, which goods and services must be delivered to the private sector, which can be done together, and which is purely done by the government.

\section{RESEARCH METHODS}

This study aims to explain the causal relationship between research concepts and hypothesis testing in order to make decisions inductively or generatively, so this research is descriptive and verification.

The use of descriptive analysis that is, describes the independent variables and the dependent variables that will be the basis of theory or theoretical study in research that contains the arguments or arguments of the variables under study. Uma Sekaran (2005) explains verification analysis carried out to test hypotheses using statistical test equipment. In this study, the data analysis method used to test the hypothesis is SEM (Structural Equation Model) analysis.

The research is located at the District / City Office of Trade and Industry in West Java Province. The place and location of the study is in West Java Province.

Data collection techniques for the purposes of research analysis using data collection techniques through questionnaires and observations. 
The study was conducted on State civil servants (ASN) who provide public services to the public directly (on the spot), in this case the researchers wanted to measure the performance of public services at the District / City Trade and Industry Office in West Java Province. Therefore, members of the population are all State Civil Apparatuses from the District / City Department of Trade and Industry that mostly perform the service function to the community.

Data on the role of leadership, organizational commitment, competence, organizational culture of the apparatus analyzed are data from questionnaires filled out by the State civil servants who provide services to the Regency / City Regional Apparatus in West Java Province. Likewise, data on measuring the performance of public services are measured based on the perception of the State civil service that provides services to the public.

The sample is part of the number and characteristics possessed by the population. If the population is large, and the author is not possible to learn everything that is in the population, this is because of limited funds, manpower and time so the writer can use a sample. The conclusion can be treated for the population (Sugiyono, 2010: 91).

The sampling technique according to Sugiyono (2010: 91) basically can be grouped into two namely probability and non-probability. Probability sampling includes random samples, proportionate stratified random, disproportionate stratified and random areas. Non probability sampling includes systematic sampling, quota sampling, accidental sampling, purposive sampling, saturated sample and snowball sampling. The sampling technique in this study the authors use proportional stratified random sampling. The reason for this technique I use is because members of the population are not homogeneous with a stratified educational background. The sampling technique was carried out in two stages. The first stage is where the researcher purposely determines the Regency / City Regional Apparatus in West Java Province. most provide services to the public. Considering that the Regency / City Office of Trade and Industry in West Java Province has more to do with policy making, decision making, and implementation of supervision, in this study the research is limited to the level of Section Heads, Subdivision Heads, and Staff / Implementers so that the number of State civil apparatus (ASN) which provides public services to the public directly as many as 12,782 ASN. The significance level set in the study was 5 (five) percent or $(\square=0.05$ ).

$\mathrm{N}$

then $: \mathrm{n}=$

$$
\text { N. } d^{2}+1
$$

where : $\quad \mathrm{n}=$ Number of Samples

$\mathrm{N}=$ Total population

$\mathrm{d}=$ Precision established $(5 \%)$

So,

$\mathrm{n}=\frac{\mathrm{N}}{\mathrm{N} \cdot \mathrm{d}^{2}+1}=\frac{12782}{12782(0,0025)+1}$

$=387,86$ Employee, Full rounded up to be 390 ASN. 


\section{FINDINGS AND DISCUSSION}

Based on the results of observations, interviews with various parties involved and indepth analysis of the answers of respondents, as well as their association with applicable theories and phenomena that occur in the field, it is necessary to have descriptive discussions.

\section{a. Role of Leadership}

For government agencies the availability of qualified and professional leaders is a requirement in order to improve the quality of state administration and the quality of government services to the community. Based on the results of descriptive analysis, it can be seen that the average value of respondents' answers is 3.065 with a standard deviation of 0.601 so that it falls into the bad to good category. This indicates that the Leadership Role of the heads of offices in the district / city trade and industry service in West Java Province is already not good but it still needs to be improved in terms of interpersonal. Interpersonal dimensions are dimensions with the smallest average value compared to other dimensions. Interpersonal itself is one of the fundamental factors in leadership.

\section{b. Organizational Commitment}

Based on the results of the descriptive analysis, it can be seen that the average value of the respondents' answers is 3,435 with a standard deviation of 0.756 so that it falls into the good enough to good category. This indicates that the Organizational Commitments owned by the state civil apparatus in the District / city Trade and Industry Office in West Java Province are good enough but still need to be improved in terms of sustainability commitments. Continuation commitment is the dimension with the lowest average value compared to affective commitment and normative commitment. The low value of continuing commitment can be caused by rewards or punishments that are not appreciated well by employees. The rewards referred to here are not only rewards for employee work but also include praise or flattery from superiors on the achievement of performance completed by employees.

\section{c. Competence}

Competence as in terms of skills, abilities, and authority. Besides that, it also has the same understanding as capability (capability), someone who is competent who has the ability, knowledge and expertise to do something efficiently and effectively.

\section{d. Cultural Organization of the State civil apparatus.}

Based on the results of the research findings, it can be seen that the average value of the respondents' answers is 3.032 with a standard deviation of 0.859 so that it falls into the bad to good category. This indicates that the culture of a good state civil apparatus is in accordance with the facts of the district / city trade and industry service in West Java Province.

e. Public Service Performance 
Based on the research findings Service Quality variables have an average value of respondents responses of 4.601 with a standard deviation of 1.257 which is in the category of good enough to very good. This indicates that the Quality of Service is good where there are employees who work at the District Office of Trade and Industry in West Java Province. Based on the research findings, the dimensions of completeness of facilities and infrastructure have the lowest average value compared to the other nine dimensions. It cannot be denied that the availability of facilities and infrastructure supporting public services in Indonesia can still be said to be low.

Based on the results of the study, interviews with various relevant parties and in-depth analysis of the answers of the respondents, as well as their association with applicable theories and phenomena occurring in the field, it is necessary to have a verification discussion. Below shows the influence of each research variable, for more details we can see as follows:

1. The role of leadership, organizational commitment and competence to the culture of the state civil service organization in the District / city Trade and Industry Office in West Java Province

The simultaneous influence of the role of leadership, organizational commitment and competence on the culture of the state civil service organization in the trade and industrial services district / city in West Java Province is $74.77 \%$. Where the results of simultaneous hypothesis testing obtained $\mathrm{F}$ count is far greater than $\mathrm{F}$ table, so it can be concluded that the leadership role, organizational commitment and competence have a very significant influence on the organizational culture of the ASN Department of Trade and Industry.

The discussion of the results of testing the hypotheses together, states that there is a significant influence, this means that the role of leadership, organizational commitment and competence is the dominant variable in shaping the organizational culture of the state civil apparatus.

The phenomenon of the organizational culture of the state civil apparatus that occurs in the District / city Office of Trade and Industry in West Java Province is not optimal, this is due to the weak Leadership Role, Organizational Commitment and limited competence.

The next interesting discussion is that the state civil apparatus itself has not been able to understand and carry out its duties on public service properly.

a. Partially from the Role of Leadership, Organizational Commitment and Competence Against the Organizational Culture of ASN Partially or separately, the relationship between research variables is explained as follows:

1) The Role of Leadership in the Organizational Culture of ASN.

Testing the hypothesis of the influence of leadership roles on ASN organizational culture, it can be concluded that the leadership role formed by 4 dimensions has a positive and significant effect on ASN organizational culture with an SEM analysis value of 0.5403 , it can be interpreted that the better the implementation of leadership roles, the higher the culture of the ASN in the Trade and Industry Office.

The findings of the research into the role of leadership on the organizational culture of ASN, the conclusion is that the role of leadership is the variable that provides the highest influence. The role of leadership significantly affects the organizational culture of ASN by $43.49 \%$, with details of the direct influence of $29.19 \%$, and the indirect effect of $14.30 \%$. 
Thus the direct effect is greater than the indirect effect, this shows that the leadership role variable is the dominant variable, which means that this variable can stand alone, in the sense that it is not contributed by the other two variables, the effect is very significant in shaping the organizational culture of ASN in the Department Trade and Industry. The effort to improve the role of leadership needs to be affirmed and reinforced again about its dimensions, including: Determining the direction; Change agent; Spokesman ; Trainers and mentors, so that by affirming and strengthening all of these dimensions will be able to optimize the implementation of roles leadership in enhancing the culture of the ASN organization in the Trade and Industry Office.

The results of this study are supported by several theories as follows:

1. Massi and Cooke, (2000). Which states: Leadership is proven to be able to bring about more fundamental changes, such as changes in the values, goals, and needs of subordinates and these changes have an impact on the emergence of commitment because the fulfillment of higher needs

2. Thomas and Velthouse (2000) which states that: empowerment will make employees have a higher level of concentration, initiative, and excitement which in turn will increase their commitment to work and organization.

Testing the hypothesis of the effect of organizational commitment on organizational culture ASN concluded that organizational culture formed by 7 dimensions has a positive and significant effect on organizational commitment with an SEM analysis value of 0.2394, it can be interpreted that the more effective organizational culture, the higher organizational commitment at the Trade and Industry Office.

The findings of the research into the role of leadership on organizational culture, concluded that the role of leadership is the variable that provides the smallest influence. organizational culture significantly influence employee commitment by $17.20 \%$, with details of the direct effect of $5.73 \%$, and indirect effect of $11.48 \%$. Thus the direct effect is smaller than the indirect effect, this shows that the organizational culture variable is a non-dominant variable, which means that this variable cannot stand alone, in the sense that it is not contributed by the other three variables, so the effect is not significant in forming employee commitment in Department of Trade and Industry.

As for efforts to improve organizational culture, it is necessary to affirm and reinforce its dimensions, including: Innovation and risk taking; Attention to details; Results orientation; People orientation; Team orientation; Aggressiveness; Stability, so that by affirming and strengthening all of these dimensions will be able to optimize the effectiveness of the application and implementing organizational culture in increasing employee commitment at the Trade and Industry Office.

The results of this study are supported by several theories as follows:

1. Gibson et al (2010: 183) explains that commitment is related to the creation of a conducive organizational culture.

2. Zwell in Wibowo (2011: 16) explains that culture is a pattern of shared basic assumptions that groups learn through solving external adaptation problems and internal integration. An organized group of people who share the same goals, beliefs and values, and can be measured through their influence on the formation of strong organizational commitment. 
Tests on the hypothesis of the influence of competence on ASN organizational culture concluded that the competence formed by 5 dimensions has a positive and significant effect on employee commitment with an SEM analysis value of 0.2245 , it can be interpreted that the higher the competence, the higher the culture of ASN organizations in the Office Trade and Industry.

The findings of competency research on organizational culture, concluded that competence is the variable that gives the second highest influence after the leadership role. competence significantly influences organizational culture by $14.08 \%$, with details of direct influence of $5.04 \%$, and indirect effects of $9.04 \%$. Thus the direct effect is smaller than the indirect effect, this shows that the competency variable is a non-dominant variable, which means that this variable cannot stand alone, in the sense that it is not contributed by the other three variables, so the effect is not significant in shaping the ASN organizational culture in Department of Trade and Industry.

The results of this study are supported by several theories as follows:

1. Griffin (2002: 13), Employees who have competence and high commitment to their work will provide the best service to service customers. Employee competency and commitment to service organizations is a major tool in interactive service marketing. Customers who get good service in services will recommend the product to other customers through word of mouth 2. According to Meyer and Allen (2005), suggested that employees who are strongly committed, work hard and show better performance, and are more valuable in the organization. Good work commitment, employees are expected to be able to work effectively, even beyond what should be done. 3. Griffin (2002: 13), employees who have high competence and commitment to their work will provide the best service to service customers. Employee competency and commitment to service organizations is a major tool in interactive service marketing. Customers who get good service in services will then recommend the organization's products to other customers through word of mouth.

The results of this study are in line with research from:

1. Sutrisno (2009: 202), Spencer and Spencer in Sutrisno (2013), Mulyasa (2003), Government Regulation Number 101 of 2000 concerning Civil Servants Training and Training, the Administrative System of the Unitary State of the Republic of Indonesia (SANKRI, 2003: 75-76) which stated that the combination of knowledge, skills, values, and attitudes that are reflected in the habits of thinking and acting.2. Rokhilah, Susetyo Darmanto, Journal of Media Economics and Management Vol. 29 No. 1 (2014). that with high competence will create a conducive organizational culture to improve performance.

The influence of the role of leadership, organizational commitment, and competence on the culture of the ASN Department of Trade and Industry. The simultaneous influence of the role of leadership, organizational commitment and competence on the organizational culture of the ASN Department of Trade and Industry was 74.77 percent, with an epsilon amount of 25.23 percent. Where the results of simultaneous hypothesis testing obtained $\mathrm{F}$ count is far greater than $\mathrm{F}$ table, so it can be concluded that the leadership role, organizational commitment and competence have a very significant influence on the organizational culture of the ASN Department of Trade and Industry. 
This means that the leadership role, organizational commitment and competence of the ASN organizational culture of the Department of Trade and Industry. Is a dominant variable in shaping the organizational culture of the ASN Department of Trade and Industry. The other variables that influence the commitment but are not examined (epsilon), namely: Compensation, communication, work infrastructure, job satisfaction.

Testing the hypothesis of the influence of ASN organizational culture on the performance of public services, it can be concluded that organizational culture formed by 7 dimensions has a positive and significant effect on employee commitment with SEM analysis value of 0.921 , it can be interpreted that the better the organizational culture of ASN, the higher the service performance public at the Department of Trade and Industry.

The findings of the ASN organizational culture research on the performance of public services, concluded that the ASN organizational culture is a variable that gives a very significant influence. this shows that the organizational culture variable ASN is a very dominant variable in shaping public service performance.

As for efforts to increase commitment, it is necessary to reaffirm and strengthen its dimensions, including: Affective Commitment Continuous Commitment; Normative Commitment, so that by affirming and strengthening all of these dimensions will be able to optimize the effectiveness of the application and increase employee commitment in improving employee performance in the Department of Trade and Industry.

The results of this study are supported by several theories as follows:

1. Simanjuntak, (2011). Factors that influence performance, namely, individual factors: namely the ability, skills, family background, work experience, social level, demographics of a person, the level of commitment from employees to the organization.

2. Robbins, (2008). There is a positive relationship between organizational commitment and work productivity, it generally appears that affective commitment has a closer relationship with organizational outcomes such as employee performance and turnover when compared to the other two dimensions of commitment.

\section{CONCLUSION AND SUGESTION}

1. Conditions for the implementation of leadership roles in the District / City Office of Trade and Industry in West Java Province. in the category of Poor to Good, this indicates that the role of leadership the Regency / City Trade and Industry Office in West Java Province has not been optimal. The highest aspect is my leader has the ability to provide inspiration and hope, while the two weakest aspects consist of: My leader has the ability to be a good listener, and my leader can play a role as a mentor in the agency. Conclusions about the condition of this leadership role are supported by interviews with expert judgment, which states that the role of leadership in the District / City Trade and Industry Office in West Java Province has been carried out, however the implementation is still not effective. 
2. Conditions of organizational commitment in the District / City Trade and Industry Office in West Java Province. in the category of Good to Good, this indicates that the organizational commitment in the District / City Trade and Industry Office in West Java Province is not optimal. The highest aspect is that I feel happy while working at this institution. While the two weakest aspects consist of: I have a high emotional attachment to the Agency, and I feel I have an Agency where I work. The conclusion about the condition of organizational commitment is supported by the results of interviews with expert judgment, which states that organizational commitment in the Department of Trade and Industry of Regencies / Cities in West Java Province has increased, however the increase in organizational commitment is still not optimal.

3. The condition of the implementation of employee competence in the District / City Trade and Industry Office in West Java Province is in the category of Good to Very Good, this indicates that the competency of employees in the District / City Trade and Industry Office in West Java Province is not optimal. The highest aspect is that Employees always try to develop professional work skills, while the two weakest aspects consist of: Employees do not try to develop individual skill levels, and Employees always try to develop Education. The conclusion about this competency condition is supported by the results of interviews with expert judgment, which states that employee competencies are always developed, however, the development of employee competence in the District / City Office of Trade and Industry in West Java Province is still not optimal.

4. Conditions for implementing the culture of the ASN organization at the District / City Office of Trade and Industry in West Java Province. in the category of Poor to Good, this indicates that the implementation of the organizational culture of ASN is not yet optimal. The highest aspect is that the Agency always develops employee confidence at work, while the two weakest aspects consist of: The Agency always provides an opportunity to develop employee loyalty, and the Agency always provides the opportunity to develop employee compliance. The conclusion about the condition of the organizational culture of the ASN is supported by the results of interviews with experience judgment, which states that the organizational culture of the District / City Trade and Industry Office in West Java Province is always developing, however the implementation of the culture is still not effective. 
5. Conditions for the implementation of public service performance in the District / City Office of Trade and Industry in West Java Province. Being in the category of Good to Very Good, this indicates that the performance of public services in the District / City Trade and Industry Office in West Java Province is not optimal. The highest aspect is that Employees have the ability to find new work procedures while the two weakest aspects consist of: Employees have the ability to use materials as needed, and Employees have the ability to master the task.

The conclusion about the condition of the performance of public services is supported by the results of interviews with expert judgment, which states that the employment of employees at the District / City Trade and Industry Office in West Java Province has increased, however the increase is still not optimal.

6. The magnitude of the influence of the role of leadership has a significant effect on the organizational culture of the state civil apparatus, with a magnitude of influence of $43.49 \%$. This conclusion is in line with the statement of expert judgment which states that an effective and consistent leadership role will be able provide a significant influence on improving the organizational culture of the State civil apparatus in the District / City Trade and Industry Office in West Java Province.

7. The magnitude of the influence of organizational culture on organizational commitment significantly influence the organizational culture of the state civil apparatus, with a magnitude of influence $17.20 \%$. This conclusion is in line with the statement of expert judgment which states that a high, conducive and dynamic organizational culture will be able to provide a significant influence to increase the commitment of employees of the District / City Office of Trade and Industry in West Java Province.

8. Competence has a significant effect on the organizational culture of the state civil apparatus, with a magnitude of influence of $14.08 \%$. This conclusion is in line with the statement of expert judgment which states that high and relevant employee competencies will be able to have a significant influence on improving the organizational culture of the State civil apparatus at the District / City Trade and Industry Office in West Java Province.

9. Magnitude of influence The role of leadership, organizational commitment and competence on the organizational culture of the State Civil Apparatus in the District / City Trade and Industry Office in West Java Province with a total influence of 74.77 
percent. While the amount of other variables not examined and also influenced the performance of 25.23 percent. The other variables are referred to as: work environment, compensation, communication and so forth. This conclusion is in line with the statement of expert judgment which states that the role of leadership, organizational commitment and competence developed simultaneously, where the development is effective, high and sustainable will be able to provide a very significant simultaneous influence on improving the organizational culture of the State Civil Apparatus.

10. Magnitude of influence The organizational culture of the State Civil Apparatus has a significant effect on the performance of public services with a magnitude of influence 84.87 percent. While the amount of other variables not examined and also influenced the performance of 15.13 percent. Other variables are referred to as work morale, work loyalty, job satisfaction, and so on. This conclusion is in line with the statement of expert judgment which states that organizational culture The high and consistent State Civil Apparatus will be able to provide a very significant influence on improving the performance of public services of the District / City Trade and Industry Office in West Java Province.

\section{REFERENCE}

Achmad Ruky. 2003. Sumber Daya Manusia Achmad Ruky. 2003. Sumber Daya Manusia Berkualitas, Jakarta: Gramedia Pustaka Utama.

Anwar Prabu Mangkunegara. 2011. Manajemen Sumber Daya Manusia. Bandung : Remaja Rosdakarya.

Anwar Sanusi.2011., Metodologi Penelitian Bisnis, Salemba Empat, Jakarta.

Armstrong, Michael (2010), Essential Human Resource Management Practice, Kogan Page, London Philadelphia New Delhi.

Azwar. (2008).Penyusunan Skala Psikologi. Yogyakarta: Pustaka Pelajar.

Bateman Thomas S., Scott A. Snell. 2009. Management The New Competitive Landscape, $6^{\text {th }}$ edition, New York America : McGraw-Hill Irwin

Bennet Silalahi, 2004. Corporate Culture and Performance Appraisal, Jakarta : AlHambra.

Bernardin and Russell, JEA. 2010. Human Resources Management, New York : Mc. Graw Hill Inc.

Burwash, Peter. 2007. The Key To Great Leadership Rediscovering the Principles of Outstanding Service. Badger CA, USA: Torchlight Publishing, Inc.

Carol Kennedy. 1999. Managing with the Gurus : Panduan Inti 20 Teknik Manajemen. Jakarta: Elex Media Komputindo.

Chowdhury, Subir. 2000. Management 21C. English: Financial Times Prentice Hall.

Cooper, Donald R \& Pamela S Schindler. 2006. Business Research Methods $9^{\text {th }} \mathrm{ed}$. Alih Bahasa Budijanto dkk. Jakarta : Media Global Edukasi. 
Davis, Keith dan Newstrom John W. 2004. Perilaku Dalam Organisasi,Terjemahan Sonny Sumarsono, Jakarta: Erlangga.

DeCenzo, David, dan Robbins, Stephen P. 2010. Human Resource Management, Wiley.

Dessler, Gary. 2015. Manajemen Sumber Daya Manusia, Edisi 14. Alih Bahasa

Engkoswara, 2012. Studi Kecenderungan Kehidupan di Indonesia 25 Tahun Era

Pembangunan Nasional Jangka Panjang Kedua dan implikasinya terhadap

Kualitas Manusia dan Pendidikan, Bandung : LPIKIP.

Ferdinand. 2011. Structural Equation Modeling Dalam Penelitian Manajemen, Aplikasi Model-Model Rumit Dalam Penelitian Untuk Tesis Magister dan Disertasi Doktor, Seri Pustaka Kunci, Semarang : Badan Penerbit Universitas Diponegoro.

Gary, Yukl. 2010. Kepemimpinan Dalam Organisasi, Penerjemah: Budi Suprianto, Edisi 5. Jakarta : PT. Indeks

Gareth R.Jones,and Jennifer M. George. 2016. Essentials of Contemporary Management 7 ed. English : McGraw-Hill Education.

George Jennifer M., Gareth R. Jones (2012), Understanding and Managing Organizational Behavior, sixth edition, Person Education Inc, USA.

Gibson, et,. al., 2010, Organizations: Behavior, Structure, Processes, $14^{\text {th }}$ Editions. New York : McGRaw - Hill Companies.

Gilley,J.,\& Maycunich, A. 2000. Beyond the learning organization: Creating a culture of continuous development through state-of-the-are human resource practices. Cambridge, MA: Perseus.

Griffin, Ricky.W. 2000. Business, 8th Edition. NJ: Prentice Hall.

----------,2004. Manajemen, alih bahasa: Gina Gania, Jakarta: Erlangga.

Hardiyansyah.2011. Kualitas Pelayanan Publik. Konsep, Dimensi,Indikator dan Implementasinya. Yogyakarta: Gava Media.

Hayat. 2017. Manajemen Pelayanan Publik. Edisi 1. Jakarta : Rajawali Pers

Howard, Ann dan Phil Harkins, Marshall Goldsmith. 2006. The Art \& Practice of Leadership Coacking, Jakarta : PT.TransMedium

Husaini Usman. 2013. Manajemen (Teori, Praktik dan Riset Pendidikan), Jakarta:PT.Bumi Aksara.

Ivancevich John M., Robert Konopaske, Michael T. Matteson. 2007, Perilaku dan Manajemen Organisasi, edisi ketujuh, terjemahan, Erlangga, Jakarta.

Juniarari. 2011. Komitmen Organisasi. Jakarta : Diktat.

Koentjaraningrat. 2001. Kebudayaan, Mentalitas dan Pembangunan.Jakarta : PT. Gramedia.

Kreitner, R. \& Kenicki A. 2000. Organizational Behavior 5th edition, Boston : Mc GrawHill.

Lijan Poltak Sinambela,dkk. 2011. Reformasi Pelayanan Publik. Jakarta : Bumi Aksara.

Lussier, Robert N. dan Achua, Christopher F. 2001. Leadership: Theory, Application, Skill Building. Pennsylvania State University : South Western College Pub.

Luthans, Fred, 2005. Organizational Behavior, 7-ed. New York : Mc. Graw-Hill International.

--------2006. Perilaku Organisasi, Edisi 10, Yogyakarta: Penerbit Andi.

Manz, Charles C. \& Henry P. Sims, Jr. 2006. Super-Leadership: Leading Others To Lead Themselves. NewYork: Berkley Books.

Meyer, J.P. and Allen N.J. 2004. Commitment in the Worldplace Theory Reserch and Application. Terjemahan Panggabean, California: Sage Publications.

Sidik Priadana, Dedi Hadian, 2013.,Paradigma Kepemimpinan di Indonesia, Cetakan Kesatu, Logoz Publishing \& STIE Pasundan Press, Bandung 
Mondy, Wayne.2008.Manajemen Sumber Daya Manusia, Jilid 1 Edisi 10. Jakarta : Erlangga

Mudrajat Kuncoro. 2003. Metode Riset Untuk Bisnis dan Ekonomi. Jakarta: Erlangga

Mulyasa, 2003. Kompetensi, Konsep, Karakteristik, dan Implementasi, Cetakan ke-3, Bandung: Rosdakarya.

Mutiara S. Panggabean. 2004. Manajemen Sumber Daya Manusia. Bogor : PT.Ghalia Indonesia

Narimawati, Umi \& Sarwono, Jonathan. 2017.Structural Equation Modeling (SEM) Berbasis Kovarian dengan Lisrel dan Amos untuk Riset Skripsi, Tesis, dan Disertasi. Jakarta: Salemba Empat.

Ogbonna, Immanuel. And Lloyd C. Harris.2000. Leadership style, organizational Culture and Performance : Empirical Evidence. The International Journal of Human Resource Management No.11,pp.766-788.

Osborne, David., dan Peter Plastrik. 2000. The reinventor's fieldbook : tools for transforming your government, San Francisco : Jossey-Bass

Paul Hersey and Kenneth H. Blancahrd, 2003. Management and Organizational Behavior (Englewood Cliffs, NJ: Prentice-Hall).

Yousef, Darwish A. 2000. Organizational Commitment as a Mediator of the Relationship between Islamic Work Ethics and Attitudes toward Organizational Change, Human Relationship Vol 53 (4): 513-537).

Yukl, Gary, 2002.Leadership In Organizations, New Jersey : Prenitice-Hall

Yuyun Wirasasmita. 2007, Uji Kelayakan Model, makalah, Universitas Pasundan.

Undang-Undang Nomor 32 tahun 2004 tentang Pemerintah Daerah.

Undang-Undang Nomor 14 Tahun 2008 tentang Keterbukaan Informasi Publik.

Undang-Undang Nomor 25 Tahun 2009 tentang Pelayanan Publik

Undang-Undang Nomor 5 Tahun 2014 tentang Aparatur Sipil Negara (ASN).

Undang-Undang RI No.23 Tahun 2014 tentang Pemerintahan Daerah

Peraturan Pemerintah Nomor 101 Tahun 2000 tentang Diklat Jabatan PNS.

Muhammad Syawalid, Nurdasila Darsono, T. Roli Ilhamsyah Putra .2015. Jurnal Judul Pengaruh Budaya Kerja, Kemampuan dan Komitmen Terhadap Kinerja Pegawai Negeri Sipil dan Dampaknya Pada Kinerja Sekretariat Daerah Kabupaten Aceh Jaya. Jurnal Manajemen Pasca sarjana Universitas Syiah Kuala Volume 4, No.3.

Reza Zarvedi, Rusli Yusuf, Mahdani Ibrahim. 2016. Jurnal Judul Pengaruh Kepemimpinan, Budaya Organisasi dan Kompetensi Terhadap Kinerja Pegawai Serta Implikasinya pada Kinerja Sekretariat Kabupaten Pidie Jaya. Jurnal Perspektif Ekonomi Darussalam Volume 2, Nomor 2.

Herlin Arisanti. 2010. Jurnal Judul Pengaruh Budaya Organisasi, Komitmen Organisasi dan Akuntabilitas Publik Terhadap Kinerja Organisasi Pada Kantor Wilayah Direktorat Jenderal Perbendaharaan Bengkulu. Jurnal Ekonomi dan Bisnis FE Unsyiah Banda Aceh. Volume 9, Nomor 2. 
Wong, C., \& Law, K. 2002. Journal The effects of leader and follower emotional intelligence on performance and attitude: An exploratory study. Journal The Leadership Quarterly, 13, 243-274.

Darwish A. Yousef. 2000. Journal, "Organizational commitment: a mediator of the relationships of leadership behavior with job satisfaction and performance in a non western country". Journal of Managerial Psychology, emerald insight Vol. 15 Issue: 1, pp.6-24.

F. William Brown, Michael D. Reilly. 2009. Journal "The Myers-Briggs type indicator and transformational leadership" Journal of Management Development,Vol. 28 Issue: 10, pp.916-932.

Dhammika, K. A. S., Ahmad, Fais Bin, Sam, Thi Lip. 2012. Journal Job Satisfaction, Commitment and Performance: Testing the Goodness of Measures of Three Employee Outcomes. Journal title: South Asian Journal of Management. Volume: 19. Issue: 2.

Adrian Thomas, Walter C. Buboltz, Christopher S. Winkelspecht. 2013. Journal. "Job Characteristics and Personality as Predictors of Job.

Boxall. 2010. Journal Employee experiences of high-performance work systems: An analysis of sectoral, occupational, organisational and employee variables. New Zealand Journal of Employment Relations. 